\title{
South Africa's e-Development Still a Futuristic Task
}

\author{
Lucienne Abrahams
}

Received: 9 September 2010 / Accepted: 14 September 2010 /

Published online: 28 October 2010

C The Author(s) 2010. This article is published with open access at Springerlink.com

\begin{abstract}
The slow pace of e-development in South Africa can be traced to a series of poor telecoms policy choices and a vacuum with respect to broader policy for framing transitions to an information society. This article traces the evolution of edevelopment in South Africa, analysing policy leadership, information infrastructure ecology, information and communication technology (ICT) industry formation, human resources capacity and ICT applications in business, society and government. It argues that it is possible that e-development will push through the barriers of bad policy, tepid regulation and national governance in those parts of the country where the infrastructure and services has become a necessity to the operation of firms and the lifestyles of households, making for perhaps six 'connected cities'. It proposes that future-oriented policy for information society evolution will need to adopt a paradigm that incorporates and integrates the elements of rapid diffusion and increasing sophistication of information infrastructure, alongside multiple factors in e-development from ICT R\&D to promoting a powerful online-content industry, in order to have greater influence in creating economic value and socioeconomic impact.
\end{abstract}

Keywords e-Development · Information society evolution · Telecommunications · ICT $\cdot$ Policy design $\cdot$ Leadership

\section{Introduction}

South Africa, a medium-sized country with a diverse population of 49.3 million, has demonstrated consistent progress in moving into the electronic age, despite limitations in its policy and regulatory environment. Mobile telecommunications

L. Abrahams $(\bowtie)$

LINK Centre, Graduate School of Public and Development Management,

University of the Witwatersrand, Johannesburg, South Africa

e-mail: luciennesa@gmail.com 
networks have spread across the country; sophisticated information and communication technology (ICT) applications have been adopted by businesses and government; and the Internet provides a foundation for information flows and transactions in banking and financial services, universities and other scientific performing agencies, as well as in shopping and entertainment services.

However, this e-development excludes large numbers of the population and large parts of the country, where there is limited or no access to advanced communications or e-services at the household or firm level. Thus the digital divide of the early twenty-first century parallels the racial and class divide of the previous three centuries. The majority of the African black population still live in low-income households with limited access to global communications infrastructure and services; while the minority population (defined as Whites, Coloureds and Indians) has differentiated, but nevertheless disproportionate access in relation to the country's demographic profile [47]. There is also a geographic divide with respect to edevelopment, with little advance in ICT-enabled development outside the six metropolitan municipalities.

Progress on e-governance is patchy at best, with very few public services available online or through other ICT channels. E-business has evolved in large-scale enterprises, in particular, in service industries such as banking and finance, tourism, hospitality and entertainment. While small, medium and micro-enterprises (SMMEs) have a strong profile of mobile voice access, this does not translate into e-enabled businesses using a combination of mobile voice, Internet and small-scale ICT applications. E-society is evolving slowly, partly due to the high investment required per household with respect to computer ownership and broadband Internet usage.

This article reviews South Africa's e-development from the perspectives of leadership, infrastructure, ICT industry development, human resource capacity and the contribution of these elements to the formation of e-government, e-business and e-society [19].

\section{Leadership: Policies and Institutions 1996-2009}

The slow pace of e-development raises questions regarding the efficacy and value of telecoms policy choices to date, and points to a vacuum with respect to broader policy for framing transitions to an information society. Policy and regulatory design in relation to infrastructure competition, technology and services innovation, access pricing, quality of service, stimulating investment in next-generation networks, encouraging universal connectivity and service, and promoting a local content industry are key issues that still require the attention of policy makers and regulators in South Africa today.

The limited evolution of e-development can be tracked against the slow shaping up of the policy environment in the 16-year period since the first democratic elections in 1994. Information society policy has been dominated by the Department of Communications which holds an infrastructure mandate, while departments that could offer policy or strategy interventions such as Trade and Industry (focus on edevelopment for business and SMMEs), Public Service and Administration (focus on e-government), Health (telemedicine) and Education (focus on online educational 
content and scholarly publications) have made little input in terms of creating the conditions for e-development.

E-development has been fostered largely through the introduction of services innovations such as mobile pre-paid services, the subsequent offering of small units of airtime and $\mathrm{SMS}^{1}$ bundles, as well as the availability of cheap new and secondhand handsets. Hence, South Africa is a country with a large mobile user base, typically using small units of airtime for voice communications and a limited market for broadband Internet access at current market prices.

\section{Information Society and Development 1996}

In one of its first international information society policy initiatives, the South African government hosted the ISAD (Information Society and Development) conference in Johannesburg in 1996. The South African position paper presented an 'information community perspective' highlighting the following issues: inclusive participation of developing countries as producers in the information society, not merely as ICT consumers with continued technological dependence on the developed world; fostering IT innovation capacity in the developing world as one means to address global political power imbalances and their further entrenchment in the twenty-first century; and the desire for the information revolution to benefit 'society as a whole' [39: pp. 12-20]. The future that was not precisely captured, but was envisaged in this document, was of an almost unimaginable array of wireline, wireless and mobile technologies, and the Internet, little understood in 1996.

The ISAD conference was a precious moment in history, coming just 2 years after the first democratic elections in South Africa. However, there was no naivety with respect to how difficult it would be to address the technology requirements of developing countries and of countries on the African continent. The chairperson's conclusions to the ministerial meetings argued that the technology gap was increasing between the highly industrialised and less-industrialised countries, while developing countries had their own particular needs and should mobilise investments for information infrastructure, multimedia industries and skills development. Based on this thinking, the post-ISAD review paper 'Towards the information society in South Africa' [33: pp. 8-10] motivated for national IT policy to complement existing policy on telecommunications, and science and technology in order to set the frame for complementary actions in government and civil society. A case was made that the three factors necessary to move into the information society were flexibility, infrastructure and people [4: p. 3]; flexibility to embrace and advance change and to avoid 'creating a newly privileged information technology elite' [4: p. 3]. However, no strategic action was taken and it would be 10 years before South Africa would set out its ISAD plan. The focus for the period 1996-2006 would be telecommunications and many poor public policy choices would be made along the way. The telecommunications operators and IT service providers would reap large revenues, but much of South Africa would remain under-developed and excluded from the benefits of the information society.

\footnotetext{
${ }^{1}$ SMS is short message service
} 
Telecommunications Reform: Exclusivity Versus Competition

South Africa's telecommunications reform and electronic communications development has seen three successive periods of legislative reform, the 'exclusivity' period from 1996 to 2001 based on the Telecommunications Act 1996, the 'managed liberalisation' period from 2001 to 2006 based on the Telecommunications Amendment Act 2001 and the 'information society' period from 2006 onwards based on the Electronic Communications Act, 2005 [12: pp. 10-11]. These reforms have widely failed to meet the growing demand for affordable voice communications and fast Internet-based data communications and have therefore been paralleled by other state and private initiatives that have sought to remedy the failures. These proposed remedies include establishment of a state-owned enterprise, Infraco, to provide alternative international bandwidth for affordable broadband services and municipal broadband provisioning by the mainly metropolitan municipalities. These approaches too, have thus far borne little fruit.

The 'exclusivity' period, introduced and overseen by the Ministry of Communications, extended the monopoly status of the incumbent operator Telkom for 6 years from the date of inception of the Telecommunications Act, 1996. It established the Independent Communications Authority of South Africa (ICASA), the telecommunications and broadcasting regulator and the Universal Service Agency, now USAASA, ${ }^{2}$ whose mandate was to promote universal access and service. Hence, during the first 5-year period of telecommunications policy, competition in voice services only existed in the mobile segment of the market, in the form of a duopoly between Vodacom and Mobile Telephone Networks (MTN).

In the second reform phase, South Africa introduced the Telecommunications Amendment Act 2001 which provided for, inter alia, the licencing of a second network operator. In 2004, government introduced policy directives which were broadly interpreted as enabling value-added network services providers (VANS) to self-provide their own facilities, but then immediately argued that this had not been the intention and VANS would have to continue leasing facilities from Telkom. This was the policy of 'managed liberalisation' for the telecommunications sector, an excruciatingly slow process for opening up the market to competition in the fixedline and mobile sectors. Government often intervened directly in the award of licences to telecoms companies, holding back new market entrants, first Cell $\mathrm{C}$ in the mobile market, then Neotel in the fixed-line market. Delays of several years in each case have resulted in these late entrants battling to gain a foothold in a fast-changing market characterised by disruptive technologies. Government policy had the effect of stifling competition at the level of fixed and mobile voice services, while at the same time limiting opportunities for competition in the infrastructure segment of the market. Thus the market remained restricted and consequently consumer prices remained high. Despite a requirement in the Electronic Communications and Transactions Act of 2003 that a policy be drafted for SMME access, no specific policy to support better access to ICTs for SMMEs was developed until the ISAD Plan was finally released in late 2007. The Plan includes SMMEs as one of the

\footnotetext{
${ }^{2}$ Universal Service and Access Agency of South Africa
} 
priority focus areas, but does not volunteer any practical supply-side measures to reduce prices for the benefit of this or other key economic sectors. Nor does the Plan carry through recommendations from the analysis of the potential value of ICT to such businesses [55: pp. 63-67].

The introduction of the Electronic Communications Act, 2005, set the foundation for greater market liberalisation and convergence in networks and services, providing for electronic communications network service (ECNS) and electronic communications service licences which would enable ICASA to licence nearly 500 industry players. Notably, ICASA did not proceed with this licencing initiative immediately following promulgation of the Act. It took a High Court challenge from the company Altech, an ICT products and services company, to make this change. In September-October 2008, South Africa's e-development experienced an unexpected shift. After more than a decade of telecommunications policy limiting the opportunities for e-development, a court ruling prevented the Minister of Communications from appealing against an earlier High Court decision that VANS could build their own networks. This decision unlocked the opportunity for several hundred voice and data carriers to be licenced to build their own facilities networks $[21,53]$ and thus avoid the very expensive facilities leasing and interconnection costs that have been a feature of the South African telecoms market.

Looking back, this might have been something of a turning point for South Africa. But the costs of building network facilities on one hand and the slowness in spectrum allocation on the other has seen the legislation provide little comfort to either providers or consumers. Under this current regime, the mobile and Internet markets have grown less because of government policy than despite it.

South Africa's policy uncertainty whether it is 'to be or not to be' an information society, is reflected in successive years of poor Internet access 2000-2006 [36], but has experienced a renewed surge since 2008 to around 5.3 million users in 2010, largely due to easier availability and price reductions in ADSL and mobile broadband [17: p. 137]. However, high computer hardware and bandwidth prices relative to the income of the majority of households has not brought affordable Internet access or widespread usage of advanced ICT services such as banking, shopping, education and entertainment within reach. Despite an exponential increase in mobile telecommunications access, with figures reaching about 34 million subscriptions in 2009, continued high mobile data prices may limit demand for accessing Internet services from a mobile phone.

ISAD and e-Government 2006

Late in 2006, government released the National ISAD Plan. Ten years had elapsed from the heady days of the ISAD conference and the information society still seemed as distant as it had in 1996. There is little in the text that was not contained in the South African government 1996 ISAD position paper, except for the fact that there is a dumbing down of the issues in the 2006 plan. The rather absurd and plainly false statement is made that:

'The South African ICT policy and regulatory environment is globally recognised as being amongst the best in the world' [55: p. 3]. 
South Africa's policy and regulatory dispensation had been roundly criticised from several quarters both at home and abroad [20], with few if any complimentary views expressed.

The ten pillars of the ISAD Plan were theoretically the appropriate onesconducive policy and regulatory environment; ubiquitous access to ICT infrastructure and services; local content; digital inclusion; human capital; research and development (R\&D); coordination and integration; funding; institutional mechanisms and monitoring and evaluation [55: pp. 3-5]. But the rhetorical nature of the statements must have made it impossible for even the most professional public servant to seriously pursue any particular course of action. The ISAD plan fell on several swords: (a) lack of strategy-there were just too many imperatives, objectives, pillars, principles and targets to give any clarity to the mission and purpose of government; (b) the actions of government were contrary to the stated intentions as regards a 'predictable, investor friendly, enabling policy and regulatory environment; (c) some of the statements were beyond the ambit of ISAD such as the requirement to develop a sustainable science, technology and research sector'. As regards the latter point, a simple statement on ICT R\&D would have sufficed. The expansive statement on R\&D in the ISAD Plan suggests a lack of awareness on the part of the drafters regarding the already substantial work done by other government agencies to foster a twenty-first-century system of innovation, explaining their inability to craft an appropriate positioning for ICT R\&D. Finally, (d) there are some incomprehensible confusions such as the confusion of broadband and broadcasting, possibly due to a typographical error [55: p. 29].

The ISAD plan and e-government policy presented opportunities to build information society capacities on the foundations laid by infrastructure legislation and regulation. Granted that the legislative base of the early twenty-first century had distinct weaknesses (discouraging competitive pricing, absence of a frame to encourage the emergence of broadband infrastructure necessary for converged services, a weak sector regulator, other), information society policy could, in theory, set the stage for change. However, information society policy fell under the same ministry as infrastructure policy and legislation, hence, infrastructure policy was always going to lead. The telecoms sector stakeholders were few in number and had (and still have) sizeable, unique interests in growing the size and profitability of the fixed-line and mobile voice markets. They are in a powerful position vis-à-vis the ministry due to their positioning as infrastructure providers in South Africa and on the African continent, infrastructure which governments rely on as the basis for valued added communications and transactions services. The information society stakeholders, on the other hand, were many (undersea cable consortia, Internet service providers (ISPs), VANs, WASPs, higher education bandwidth consortia, public and community advocacy groups, online content producers, municipal governments), with diffuse interests and still embryonic Internet-based service offerings. Thus, the former stakeholder grouping could exert strong influence on ICT policy, while the latter grouping did not yet have the muscle to shift the telecoms monolith of industry and government.

It is curious that very powerful industry stakeholders, such as the major banking and financial institutions who are high-volume users of voice and Internet services, did not lobby for more competitive pricing as a means to encourage the growth of ecommerce and e-business. 
But there were other reasons for the lack of traction in information society development. Responsibility for the information society focus and the e-government focus fell under two separate ministries; communications, and public service and administration, respectively. The Minister for the Public Service and Administration (1999-2008) posed some difficult questions for government:

'Any incremental improvement in public services through ICT spent should positively impact on millions of people. Can we really say that this is the case? How many ICT projects that have been delivered in the past few years have contributed positively to the millions of people in South Africa?' [13]

An overview of e-government policy points to a number of weaknesses. While the Presidential Review Commission (PRC)report (1998) highlights the need for alignment between information technology infrastructure on one hand and modernised electronic government on the other hand [37]: Chapter 6), the first egovernment policy entitled Electronic Government: The Digital Future [9] takes a technology and e-administration angle, neglecting the potential of online media (Internet and mobile media) to create value for communication between government, citizens and communities. There are only six references to the Internet, two references to web sites and one reference to cellphones in the entire document, all generic statements with little policy direction:

'...means of communication: desktop and handheld computers, telephones and cellphones, self-service kiosks and ATMs...' [9: p. 4]; '...cheap and fast access to the Internet...' [9: p. 5]; 'South Africa is counted among the countries that lack laws governing Internet crime...' [9: p. 12]; 'E-government is premised... on the availability of the Internet, and if Websites are compromised, then government data can be read or modified...' [9: p. 20]; 'Political statements, industrial espionage and thievery are all reasons for cyber-terrorists to attack Web sites...'[9: p. 20].

The overwhelming concern of the policy is IT and information security. While this was a valid concern in the early days of the twenty-first century, the emphasis on securing information, rather than on making information readily available through these new media, must have played some role in holding back progress of egovernment. There are several (17) references to access (to the Internet, to government services, to IT infrastructure, for previously disadvantaged communities), however, they are so vague as to render them meaningless. There is a single reference to 'health consulting and telemedicine' and no references to e-learning or education utilising electronic media, this at a time when e-health applications, services and technologies were already being introduced in public services across the world. It would seem that the policy had not done enough to create the basis for electronic media to impact on the lives of millions of people.

The ISAD Plan raises the e-health and e-education objectives and a later document South Africa's e-government journey [10] prioritises six pro-poor services including registration of births and deaths, and social grant applications. However, slow progress is reported. Limited content is available for e-education and there is no programmatic work on content development and management for the public 
education sector; while telemedicine is practised in only a few locations [35] and the collaborative intergovernmental platforms required for e-enabling the six pro-poor services were not yet established [58].

The Information Society Leadership Ecosystem

In the period 1996-2009, public policy and practice has evolved to promote governmental and private sector investment in knowledge-intensive activity focused on creating the platform for economic competitiveness in advanced manufacturing, biotechnology, ICT research and development, and the film and creative industries, with the national Department of Science and Technology and the Western Cape and Gauteng provincial governments directing some initial public investments towards these areas. However, South Africa does not have a broad ICT policy to promote affordable access to ICT infrastructure and high bandwidth, and to commercial and social content. It has been unable to achieve Benkler's objective [3: p. 3], that is, to place 'the material means of information and cultural production in the hands of a significant fraction' of the country's population. Its e-development path has emerged from a range of initiatives across a wide spectrum of activity, with private sector innovation and non-governmental activism being dominant; and government policymaking often creating barriers rather than a broadly enabling environment.

\section{Information Infrastructure Ecology}

Availability and affordability of information infrastructure has been a binding constraint on South Africa's more rapid and inclusive e-development. As regards ICT networks and services, though access to advanced communications such as broadband is limited by lack of effective competition, South Africa has a relatively vibrant private and public ICT sector. The range of new electronic media available provides a reasonably sound foundation for e-business, e-commerce and egovernment, including innovations in mobile banking and mobile commerce, as will be discussed below. According to the annual financial statistics for 2008, the transport, storage and communication sector (including postal and telecommunication) contributed more than 500 billion Rands to the country's economic activity [50: p. 71]. While data for the communication sector is neither updated nor disaggregated in a 2006 statistical report, the estimated total income for the post and telecommunication industry in 2006 was 137.3 billion Rands (about USD17.8bn ${ }^{3}$ ) [49: pp. $4-6]^{4}$ or $0.08 \%$ of GDP, ${ }^{5}$ with the largest contribution being from mobile telecommunications, followed by fixed-line, Internet, equipment sales, broadcasting, postal and courier services.

\footnotetext{
$\overline{3}$ At a rate of ZAR7.5 to the USD

${ }^{4}$ This large sample survey of post and telecommunication is conducted every 3-5 years, 2006 is the latest survey year.

${ }^{5}$ South Africa is listed at 26 with a GDP of USD254.9bn in a listing of GDP by country for 2006, see http://www.nationmaster.com/graph/eco_gdp-economy-gdp\&date=2006 Brazil, Russia, India and China fall in the top 12 countries on this list
} 
There has been extensive network investment over the last 15 years, of which the main advance has been in mobile networks and fixed-line backhaul, with limited growth in fixed-line or fixed broadband infrastructure. The fixed network has extensive reach yet limited uptake, while the mobile network reaches to even the most far-flung corners of South Africa, fostered by a combination of tourism development and a rapid decline in the cost of handsets and airtime in recent years. Here follows an overview of the telecoms network infrastructure and international bandwidth landscape.

\section{Telecoms Market Structure}

The telecoms market is comprised of fixed-line network operators Telkom and Neotel; and mobile network operators Vodacom, MTN, Cell C and Virgin Mobile. Under-serviced area licences were awarded to 14 small operators to provide telecommunications services in areas recorded as having less than 5\% teledensity and as having limited commercial viability. In 2008, these companies were granted ECNS licences under the Electronic Communications Act, 2005, allowing them to build their own network infrastructure, though this may be costly. In addition, more than 400 firms, including around 250 ISPs are licenced to provide telecoms and other value-added network services and to self-provide their own network infrastructure. However, the limitation on available spectrum has meant that these small firms cannot pursue wireless provisioning strategies, a more efficient option as compared to building fixed network infrastructure. Thus, competition in the telecoms market is effectively stymied by the high cost of self-provisioning for small players and by the ineffectiveness of the regulator with respect to spectrum allocation.

Telkom SA, the incumbent network operator that emerged from the predemocracy Department of Posts and Telecommunications, has held an effective 18-year monopoly on fixed-line voice infrastructure since incorporation as a public company in 1991, as well as a monopoly in fixed-line data and broadband infrastructure in more recent years. It has harvested increasing profits, while maintaining monopoly prices in relation to consumers and monopoly rents in relation to facilities leasing. Several independent studies have confirmed that a range of Telkom's prices, particularly local call charges and broadband, are far higher than in many other countries [44: pp. 111-126]. In its 2009 results, Telkom reported a 5year trend of decline in its fixed access lines from 4.7 million in 2005 to 4.4 million in $2009^{6}$ including public payphones [54: p. 86]. In a declining fixed-line market, Telkom is attempting to expand away from its traditional fixed-line infrastructure and voice business into the broadband, wireless voice and mobile data markets [54: pp. 4-5]. While it offers high speeds of between 2 and $1551 \mathrm{Mbps}$ for wide area networks operated by businesses and large organisations, its residential broadband speeds of $4 \mathrm{Mbps}$ at the upper end compares unfavourably with $24 \mathrm{Mbps}$ in markets like the UK and India. While the company expresses its intentions to rebalance tariffs with respect to both local and international pricing, this is not reflected in prices to the consumer, where average monthly prices increased $11 \%$ between 2008 and 2009.

\footnotetext{
${ }^{6}$ Year ending March
} 
Neotel, the second network operator, only launched services to consumers in mid2008 and so far there has been little impact on prices in the sector from this new market entry. Nevertheless, Neotel has implemented an aggressive marketing campaign, promising a connection within 48 hours, compared to the lengthy waiting period for a Telkom landline. The Neotel customer base has developed some depth only from 2009, with deployment of fibre to the desktop, giving a household subscriber base of between 30,000 and $50,000 .{ }^{7}$ The company strategy appears to be to focus on building its market share through providing new technologies and added value, rather than engage in full-scale price competition with Telkom.

The South African mobile operators Vodacom and MTN have a continental presence in Africa and the Middle East. Collectively, the two groups have more than 130 million subscribers, ${ }^{8}$ of which 44.7 million plus are in South Africa, not accounting for multiple and inactive sim-cards. An exemplar of rapid expansion, MTN's local subscriber base grew from 200,000 in 1996 to 17.1 million in 2009 [27, 57]. While Vodacom and MTN are the dominant players in the market, late entrant and third mobile operator Cell $\mathrm{C}$ is estimated to have around 7 million subscribers and is set to introduce 4-G technology at speeds of $21 \mathrm{Mbps}$. Virtual mobile operator, Virgin Mobile, launched in 2006, adds a further 200,000 to the subscriber base $[6,56]$. While high prices remain a strong feature of the South African telecoms market, the two fixed and four mobile operators are intensely focused on keeping abreast of technology advances and convergence in technologies and services, offering an ever-wider range of commercial and household voice, data and valueadded services.

The Internet landscape has evolved slowly since the 1990s, but is beginning to show signs of more rapid development, with increasing access and usage. The number of Internet services and Internet access providers, ISPs and IAPs, increased from seven in 1994 to 603 in 2008 and 726 in 2009, of which the majority were internal corporate providers serving staff and clients of the particular company [17: p. 13], and a small proportion were independent ISPs. By December 2009, Internet access had passed the 5 million mark and is heading for 6 million by the end of 2010 .

Internet access is currently experiencing what appears to be a fundamental restructuring. Consumers and businesses who for more than a decade had relied on Telkom for voice, Internet access and international bandwidth, now have a wider market for access through mobile service providers and are likely to have even greater choice resulting from the major market changes pending. VANS providers who have taken a series of cases of uncompetitive behaviour against Telkom to the Competition Commission from 2003 to date, with only limited success, now stand on the cusp of investing in infrastructure development which could push the market towards greater competition and a downward impact on prices. Following the award of ECNS licences in 2009, the sector is awaiting the award of spectrum as one of the last remaining barriers to building new wireless networks. However, the industry regulator, ICASA, has proved slow to deliver on spectrum resource allocation.

\footnotetext{
${ }^{7}$ No figures are currently available for business usage

${ }^{8}$ Vodacom Group 39.6 million as at 31 March 2009; MTN Group 90.7 million as at 31 December 2009, see respective annual reports
} 
As Internet access grows, demand for bandwidth is increasing, in particular from business and the academic community. There are currently five broadband providers in South Africa (previously six), namely Telkom, Neotel, Vodacom, MTN and Wireless Business Solutions operating as iBurst. The 2008 Internet survey, [15: p. 46] argues that

'The premium offerings may be expensive, but for the ordinary user with average Internet needs, there is a price to suit the pockets of most working people who have computers and phones at home'.

Pricing of ADSL broadband showed a downward trend between 2004 and 2007 and South Africa witnessed a shift from dial-up to ADSL over the period 2005 to 2009. Of the estimated 630,000 ADSL connections, approximately 355,000 were for SMEs connecting an estimated 1.1 million users, though some have dual Internet access, meaning access at more than one location. Wireless broadband subscribers were reaching towards the 1.5 million mark by December 2009. Estimating access across households, SMMEs, academic and corporate institutions indicates a total of more than 4.5 million unique broadband users [17].

It is noted that these shifts come as a result of a concerted response to constraints in the telecoms policy environment and attempts to push aside the existing policy paradigm of 'managed liberalisation', rather than as a result of well-designed policy or regulation.

Given the slow introduction of broadband by private providers, some provincial and municipal governments have taken an active stance on introducing 'municipal broadband'. The City of Johannesburg has established a public-private partnership with Ericsson to build, operate and maintain a citywide broadband network, offering affordable services to public entities and low-income communities, with eventual transfer of the asset at an agreed date. But the cost of building the infrastructure and the relative difficulty of designing business models that will show commercial returns, has seen these initiatives, too, get off to a slow start. The metropolitan municipalities have historically invested in telecommunications assets for internal communication, but also own a range of assets that can be utilised for telecommunications purposes, including fibre networks, wireless networks, street light poles, storm water drains and pavements. With the current laying of highbandwidth fibre across many cities by the fixed-line operators, municipalities are establishing policy to invite greater penetration of broadband, while at the same time adopting strict guidelines for the remediation of public land.

The telecoms and broader ICT markets are high-priced markets relative to income, with respect to both voice and broadband. One of the main cost drivers has been the relatively high interconnection rates charged by operators to terminate calls on each other's networks. In 2009, the Ministry of Communication undertook a major price negotiation on interconnection rates with the sector. Rather than await a policy determination from the Ministry, the mobile operators volunteered to reduce interconnection rates commencing 1 March 2010. Telkom proposed to pass the savings on to the customer by dropping the price of peak-time fixed-to-mobile calls. ICASA aims to reduce interconnections rates every July commencing 2010 through to 2012 [14], but it is not yet clear that these rate cuts will be passed on to the consumer in terms of the cost of fixed-to-mobile and mobile-to-mobile calls. 
International Internet Bandwidth

International bandwidth has been one of the perceived bottlenecks in South Africa's e-development value cycle, but shifts are beginning to occur in the undersea cable segment of the market. South Africa is linked to the global Internet via the South Atlantic 3 (SAT3)/WASC cable along the West Coast of Africa to Europe, and by the South Africa Far East (SAFE) cable system across the Indian ocean to India and Malaysia. Four additional cable systems will have been laid by 2011 including the West African Cable System (WACS), the Africa Coast to Europe, Eassy ${ }^{9}$ and Seacom $^{10}$ [45]. The 17,000-km Seacom cable, offering high-capacity bandwidth links between Africa, Europe and Asia, went live in July 2009, with landing sites in South Africa (Mtunzini), Mozambique (Maputo), Kenya (Mombasa) and Tanzania (Dar es Salaam).

SAT3/SAFE was historically managed by Telkom with high access prices charged. With the commercial launch in March 2009, Seacom promises to offer less expensive bandwidth to the African continent and South Africa, serving what is regarded as the 'longest underserved coastline in the world' [42], connecting South Africa and countries on the continent to London and Mumbai. This potentially disruptive infrastructure deployment may shift the market for international bandwidth to provide a cheaper alternative to SAT3/SAFE, with significantly greater capacity, at $1.28 \mathrm{Tbps}^{11}$ [17: p. 20]. The Eassy cable and the WACS undersea cable will bring additional capacity of 1.4 and $3.8 \mathrm{Tbps}$, respectively. This is all in theory, however, the Seacom effect to 'enable high definition TV, peer to peer networks, IPTV and surging Internet demand' [43] is not yet a reality.

In the light of the opening up of international bandwidth and the availability of next-generation technologies, industry players are migrating towards converged digital networks to meet demand for broadband multi-play services. Universities and scientific performing agencies will be able to take advantage of increased capacity in international bandwidth and national cyber-infrastructure to support high-speed international research collaboration, through the academic research network SANRen, which will connect up to 108 sites and more than 3,000 researchers across local-international research networks [26].

\section{ICT Industry}

The broader ICT market includes a wide range of state and private providers in the realms of hardware and software provisioning, software engineering and applications design, and IT services. ICT R\&D has historically been mainly in the software field. New areas of R\&D are evolving in cyber-infrastructure, mobile technologies and applications $[11,34]$. But the level of technological advancement is low with respect to the electronics and telecoms/ICT components manufacturing sector, advances in consumer services and the related effects on society and the economy.

\footnotetext{
${ }^{9}$ East Africa submarine system

${ }^{10}$ South Africa-East Africa-South Asia fibre optic cable

${ }^{11}$ Terabits per second
} 
South Africa is a net importer of telecoms equipment and the information and computing technologies that go to make up the facilities network. While the South African government adopted an ICT Research and Development Strategy in 2007, the ICT sector is probably several decades away from making a significant contribution to local needs or to making the country a significant player in the global ICT R\&D sector. A few universities conduct R\&D in the field, giving rise to the emergence of new institutions in the past 5 years, namely The Joburg Centre for Software Engineering (JCSE), established with support from metropolitan government $^{12}$ and the ICT industry; and the Meraka Institute, ${ }^{13}$ established in 2007 with resources from the state fiscus. Meraka emerges from a long history of ICT R\&D at the $\operatorname{CSIR}^{14}$ and conducts research and experimental development in four broad fields, namely cyber-infrastructure, imaging and networks, systems engineering and applications.

The more developed parts of the R\&D ecosystem include the local electronics industry which produces vehicle tracking systems and satellite TV decoding systems for export and for local markets. Other areas of innovation include wireless technologies and mesh networking, as well as voice recognition systems for local languages, translation engines such as translate.org.za and software design and standardisation [24: pp. 271-272]. As regards ICT priorities for the productive sector, the top three priorities for innovation in 2009 were applications development, network infrastructure with due attention to broadband access, and business intelligence [41: pp. 2-3].

\section{The Information Technology Sector}

South Africa has a sizeable market for IT goods and services, estimated at USD9.5bn in 2010 [5: p. 1]. It includes the presence of multi-nationals such as IBM, Cisco and Tata, ${ }^{15}$ and home-grown companies such as Dimension Data and Arivia. Kom. There are reportedly in excess of 2,428 companies operating across the hardware, software and IT services markets, with a combined staff of 141,929 people [41: p. 2]. These companies offer services that include IT architecture and enterprise resource planning; network evolution and management; hardware and software sales; applications integration; data management; e-commerce; and a range of valueadded applications. The sector provides support to the manufacturing and resources sectors, to the broad services sector which includes non-governmental organisations and to academic and research institutions. It enables the increasing utilisation of ICT goods and services as a medium for doing business and for managing operations in all spheres of government.

By international standards, South Africa's large companies show a relatively sophisticated usage of IT both in terms of the continuous upgrading of enterprisewide systems and the introduction of converged services across IT, mobile voice and data platforms. On the other hand, small companies, employing 50 people or less are

\footnotetext{
${ }^{12}$ The City of Johannesburg

13 www.meraka.org.za

${ }^{14}$ Centre for Scientific Industrial Research, one of several scientific performing agencies

15 Through its indirect subsidiary Financial Network Services Pty Ltd (Africa)
} 
limited in their deployment of IT, except in sectors such as tourism where IT is a foundation business requirement.

The low levels of household penetration for computers, around $15.6 \%$ according to the Community Survey 2007, may begin to shift as large numbers of second-hand laptops come into the marketplace. A similar phenomenon was observed with mobile handsets where, in the period post-2005, the second-hand mobile handset market grew to the extent where the cost of owning a mobile phone was well within reach of most households. However, the cost of operating the mobile phone or computer to conduct electronic or Internet-based transactions is still beyond the budget of most households.

\section{The Content Industry}

The content industry is relatively small and still in the early stages of development. Broadcast and Internet content is generally sourced from foreign providers and websites. The local broadcast market [25] is comprised of a multimedia network operator and broadcast network provider, Sentech; the South African Broadcasting Corporation (SABC) and commercial digital satellite television broadcaster, DStv. Radio and TV broadcasting is a diverse, still largely analogue landscape. The public broadcaster, the SABC, incorporates 15 public broadcast radio stations covering all 11 languages ${ }^{16}$ and three commercial radio stations. There are 13 private commercial radio stations and 126 community radio stations licenced to operate across South Africa's nine provinces.

The TV market is dominated by the SABC's three multi-language terrestrial television channels, supplemented by the free-to-air e.tv and pay TV offering, DStv. $\mathrm{TV}$ and radio offers a programming range from news and current affairs, to drama and reality TV. Four pay-TV channels were licenced in 2007 and the company On Digital Media, branded as TopTV, has introduced 55 new channels to the market in 2010. It is certain to compete with DStv in segments such as news, sport and movies, while at the same time aiming for the low-to-middle-income market.

The major local producers of Internet content are the media sector (newspapers, radio and TV); financial, tourism and entertainment sectors; and government. The local content industry for the TV, film and advertising sectors is based almost exclusively in Gauteng and the Western Cape, and South Africa also offers facilitation services for international film and advertising crews.

South Africa's broadcast infrastructure is roughly 15 years old, but not yet obsolete. Still using analogue technologies, multi-language television channel SABC 2 has the biggest footprint and covers $80 \%$ of the country in terms of its signal, while English-language channel SABC 3 offers a more urban-focused signal. In far rural areas where there is poor TV coverage, satellite is used to convey a broadcast signal, yet there remain areas that are not covered at all. For the 2010 World Cup $^{\mathrm{TM}}$, the International Broadcast Centre at Soccer City in Soweto broadcast using both analogue and digital technologies.

Digital migration from analogue platforms to digital TV is in process. However, the initial switch-on date of November 2008 was not met and much remains to be

$\overline{16}$ The most spoken languages are Afrikaans, English, Pedi, Sotho, Tsonga, Tswana, Xhosa and Zulu 
done to ensure that the current high TV coverage for South African households does not decline due to the lack of affordability of set-top boxes and other constraints. It is argued that new channels are needed to attract people to buy the set-top boxes required for accessing the digital signal [29], presenting a particular challenge for the cash-strapped public broadcaster. Estimates indicate that government will need to subsidise approximately 4.5 million set-top boxes for low-income households. There is now speculation that the switchover for most viewers will only take place in 2014, skirting dangerously close to the 2015 deadline for withdrawal of global protection for analogue signals.

\section{Human Resources}

South Africa has a sizeable human resource base of several million tertiary education graduates, with an upward trend in higher education graduations in key sectors such as the engineering sciences, marketing and management sciences, and the health sciences [28: pp. 6-18]. However, the number of full-time researchers per thousand of the workforce is relatively low at 1.5 [28: p. 18] and doctoral graduations in the information, computer and communication technology disciplines is very low at only $4 \%$ of the total doctoral graduate pool of 1,176 for 2005 [28: p. 18]. The size of the ICT workforce including core workers and end-users ${ }^{17}$ is estimated at more than a million [2: pp. 20-21], not accounting for the large numbers of workers in the telecoms sector. While small in global terms, with unmet local demand for ICT skills, the workforce is nevertheless sufficiently large to ensure that the country's ICT infrastructure and services ranges from the most basic to the most advanced.

\section{Skills, Gender and ICT}

The limited availability of skills is a constraint to growth of the sector. The problem is less in the services sector where these tools are used, than in the productive sector where the tools are developed. South Africa had no skills base in mobile communications and its convergence with computing 15 years ago; now, large companies employ a range of skills, from technical to content skills. In the technical equipment sector, a few companies like UEC in Durban have developed a niche market with roughly 900 staff producing Multichoice digital satellite decoders for sale in the Far East, in South America, Australia and on the African continent. The large banks employ many thousands of people for information systems development and maintenance, mainly in-house. This latter is a thriving sector, but there are major shortages of software project managers, systems integration and architecture specialists, information security developers, as well as database administration and other high level developers. These skills are crucial as they form the apex of the skills pyramid needed to design new large-scale IT projects [11].

\footnotetext{
${ }^{17}$ According to the definition used in the study, core workers are engaged in the design, assembly and maintenance of computer systems, while end-users support ICT business process operations.
} 
There is a scarcity of useful statistics on ICT skills, but a few recent studies offer a perspective. The ICT workforce, incorporating both core workers ${ }^{18}$ and endusers, has been measured at various points as being around 1.1 million in 2003 with core ICT workers at around 182,800 [2: p. 21]. By 2009, core workers had increased to around 430,000 [41]. Nevertheless, a 2008 survey [40: p. 15] argues that around 70,000 core ICT workers are needed to provide the various economic sectors with the skills necessary to ensure effective utilisation of these new technologies.

Gender participation in the ICT workforce is skewed towards women [22], with a greater percentage of the total workforce $(64.4 \%$ in 2005$)$ being women. However, men dominated the workforce in the core workers component, while women were in the majority in the end-users component, 'performing administrative support and secondary ICT work activities' [22: pp. 40-41]. The lower level of women's participation in science and technology is often attributed to women's lack of technical capability. This study found that, contrary to this view, the many barriers that remain to women's greater participation in the ICT workforce include the lack of role models, salary inequities and work-family conflicts.

The broadcast industry has two major centres for production-Cape Town for shooting commercials and facilitation for international crews working in both features and commercials; and Johannesburg for the local TV content industry. Commercials from all over the world are shot in South Africa using local crews and expertise, indicating the high level of technical skills available. However, at the level of film, documentary and series, skills development is less advanced [29].

\section{ICT Applications}

ICT's contribution to the growth and development of the country has mainly occurred in the private services sector, the greatest progress being in the banking, finance, tourism and hospitality sectors, with more limited diffusion in the manufacturing sector, and only minor impact in the mining, agricultural and construction sectors. In new areas of international trade, such as the business process outsourcing market, South Africa has so far proved unable to attract expected levels of investment, largely because of the high cost of international bandwidth [8]. With regard to social communication amongst individuals and households, access to and usage of ICTs is limited to voice communications and text messaging, with only $7 \%$ of households (2007) having access to the Internet [47]. Using ICT for educational purposes is fairly extensive at the tertiary level, though the ratio of student and lecturer access differs across institutions. At secondary level, Internet access is restricted to some fee-paying schools and to public schools in a few provinces where programmes are in place.

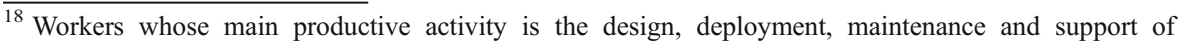
computer systems
} 


\section{Electronic Government}

E-development in the three spheres of government-national, provincial and local has had mixed fortunes. The national Batho Pele ${ }^{19}$ Gateway citizens' information portal www.gov.za and electronic filing of tax returns to the South African Revenue Services are two of the more successful applications of electronic government. But the absence of effective e-government is strongly felt in services such as the preparation and delivery of passports and identity documents, which is dogged by inefficiency and long waiting times.

At the level of South Africa's nine provinces, the Gauteng government has focused on three large-scale programmes, namely the Gautengonline schools programme, the e-Government programme (including Gauteng Emergency Medical Services and SAPS ${ }^{20}$ Gauteng) and the G-Link broadband infrastructure project, amongst a wide range of departmental and cross-governmental initiatives. The provincial government of the Western Cape has pioneered online procurement, offers the Cape Gateway ${ }^{21}$ 'easy access to government information and services' and an online educational resource repository Edumedia Online. The remaining seven provincial governments have not developed any significant online presence, though all have websites offering information about the province and the activities of provincial departments. The KwaZulu-Natal provincial government website channels visitors to the South African Government Information and Services portals, but offers no provincial specific e-services, though department specific information is available on the site. This latter province is also keen on introducing high-speed broadband access for local residents, though this is likely to be a long-term venture as much of the province is rural.

A brief review of e-government in a single province (Gauteng) ${ }^{22}$ will need to suffice here as a perspective on electronic government noting that provincial and municipal level governments are the main providers of public services to their respective populations. The Gauteng Online schools programme, started in 2002, has seen the computerisation of approximately 1,100 schools for the benefit of learners. However, a major weakness has been the lack of development of relevant local educational content. The website provides links to other sites hosting educational material, but there has been no development of an overarching e-learning programme; no learner- or teacher-focused website design; and no move to put textbooks, supporting learner materials or age-specific general knowledge online [1]. This limits the value of the school computerisation programme to the learning process, as teachers and students need a comprehensive e-learning programme that explores all existing content areas of the curriculum, introduces new ICT-enabled teaching methodologies and adds new interactive content, such as exploring virtual 3-D maps for geography lessons, or using virtual 3-D graphics of animal and human anatomy to teach biology, or downloading short film documentaries on local history in history lessons.

\footnotetext{
${ }^{19}$ People First

${ }^{20}$ South African Police Services

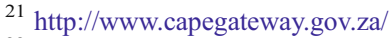

${ }^{22}$ based on 2009 study by Abrahams and Newton-Reid
} 
The Gauteng emergency services command and control centre uses the GEMS electronic system to respond to calls and dispatch emergency vehicles, to track vehicles using GIS ${ }^{23}$ technology, and to refer calls to the South African Police Services (Gauteng) when necessary. The electronic system improves on the historical use of telephone and radio, as it creates the foundation for a high quality of service with respect to the rapid identification of vehicles closest to the emergency scene and electronic tracking of patient progress. The SAPS Operations Centre (Gauteng) established in 2000 is perhaps one of the most advanced e-government operations nationally. It regularly upgrades its digital information management system and deploys high-bandwidth networks, enabling easy processing of high data volumes. The availability of comprehensive crime intelligence supports decision-making and improves responsiveness.

Advances in interactive electronic government are limited by, amongst other things, the low levels of Internet penetration with respect to households and small business. At the local government level, metropolitan municipalities such as the City of Joburg and the City of Cape Town have a well-developed web presence, but this has limited value for poor communities who do not have Internet access. Projects such as SmartCape, ${ }^{24}$ offering free Internet access and local content at community libraries across Cape Town, are therefore very important initiatives that require longterm government and industry funding and should be extended to other provinces. Only a few municipalities in smaller towns make use of electronic government, typically those with a high tax base due to being retirement and/or tourist towns.

Hence, if the middle to high-income population use a greater proportion of private as compared to public services, and the poor uses a greater proportion of public as compared to private services, then poor households experience the burden of the digital divide through the relative absence of electronic government services as compared to the increasing pervasiveness of electronic commerce.

\section{Electronic Business and Commerce}

The services sector is both the largest contributor to GDP and the sector in which the greatest usage of electronic media occurs. In the period since 1996, banking and financial services, tourism and entertainment have become powerful exponents and power users of online media.

The manufacturing sector has been slow to adopt e-business with limited B2B ecommerce for major activities such as supply cycle management, but few studies are available to track developments in this important economic sector.

The SMME sector predominantly uses ADSL (73\%), with dial-up - a thing of the past (4\%) - and wireless broadband - not yet gaining ground (8\%) [16: p. 79]. Some possible explanations for the limited attractiveness of wireless broadband include the higher cost and performance in relation to the relatively basic needs of the majority of SMMEs, which are largely based in the services sector. Also, SMME staff are likely to be less mobile than people working in large corporate organisations, government or

\footnotetext{
${ }^{23}$ Geographic information systems

24 www.smartcape.org.za
} 
academia. As regards e-business, there appears to be inadequate utilisation of ICT applications to enhance business growth and competitiveness [23].

\section{Banking and Financial Transactions}

The four largest banks, FNB, ABSA, Nedbank and Standard Bank offer Internet, telephone and mobile phone banking. By the end of 2009, 4.6 million South Africans were banking online [18]. Transactions use simple but heightened security measures, including SMS passwords for Internet banking and instantaneous SMS notifications for credit card usage. Wizzit, a division of the South African Bank of Athens Limited, is designing a service for the 12 million economically active people who are unbanked, recruiting retailers to take deposits and pay out cash, though this business model requires generating large numbers of transactions at low cost. Small, emerging banks such as Capitec, which have opened for trading in the last 12 years, are building their businesses around mobile data and Internet-based transactions as this presents a more cost-effective financial model for their operations [7].

'The tipping point appears to have been reached. Regulators have defined their legislative structure; cellphone operators have come to terms with operating in the stricter banking environment; consumers have learnt to trust transactions by phone; and banks are devising business models to make money from this service.' [7].

South Africa is awash with point-of-sale devices that enable transactions against either credit or debit cards, at restaurants, automotive service centres and most retail outlets, creating the basis for a local innovation in access to cash - the mini-ATM. Mini automatic teller machines use the same network as the already installed pointof-sale devices. The customer transacts a withdrawal and is issued with a receipt which is then converted to cash by the retailer. Since the retailer uses the existing cash taken in by the business, electronic transactions between the retailer and the banking system take the place of large physical cash transfers.

\section{Online Media and Social Networking}

New electronic media, in particular the Internet and mobile media technologies have taken root in the first decade of the twenty-first century. Most newspapers and radio stations have an online presence, with 107 online newspapers and 152 online magazines reported [25: pp. 109-112], but the Internet is used to access a much broader range of social media. Trends indicate an increase in the number of unique Internet browsers, the number of page impressions, the number of sessions, time per session and total time spent online in 2008 [32]. Of the estimated 4.7 million unique browsers, the audience demographics are predominantly male and English-speaking and nearly 50\% were older than 35 years [32]. Unsurprisingly, employment websites such as careerjunction.co.za and Careers24, personals and dating sites, real estate and automotive sites were in the top five sectors by average time per session in 2008, reflecting the main lifestyle components of users. Education and healthcare do feature 
in the top ten most engaging sectors by average time per session, but email, messaging and chat still attract the largest number of unique browsers [31]. Popular online brands include News24.com, yellow pages.co.za, Autotrader.co.za, supersport.co.za and Junkmail-za, revealing that there is growing Internet substitution for news and advertising print media [30]. This broad interest has held steady for several years now:

'...brands in the top 20 are indicative of the increasing penetration of the Internet into daily South African life. Whether its for news, health, jobs, cars, classifieds, sport or lifestyle, South Africans are turning more and more to the Internet to meet their needs.' [30]

This is confirmed by a local report on online media [16: pp. 4-5] which points to the strength of online advertising and the attractiveness of social media and social networking tools for the media, automotive and telecommunications sectors. Online advertising grew by $27 \%$ in 2007 , by $32 \%$ in 2008 and by $35 \%$ in 2009 , bringing the total online advertising spend in 2009 to R419 million [16].

Social networking sites Facebook and Twitter gained popularity in 2009, with their potential role in strengthening democracy attracting attention of users and government alike. Blogging is big with large media owners setting up blogspots like www.mydigitallife.co.za and The Times Planet Blog. More importantly, individuals and communities of interest, in school, business and academia are blogging on every topic imaginable.

Media companies have started offering online content using mobile Internet technologies and mobile Internet penetration looks set to grow, with popular sites including entertainmentafrica.mobi. Mobile websites or mobisites include online newspaper and radio content, sport, and wireless applications such as ring tones, music downloads, games, graphics and animations [25: pp. 124-127].

The print media appear to have been much more successful than the public broadcaster at repurposing their content for the online environment. This flexibility bodes well for ensuring the continued, possibly increased socioeconomic value of text as a medium of communication. The challenge for online content is access for the more than $90 \%$ of the population 15 and above who are not connected to the Internet. While mobile content provides a partial solution, it cannot provide the full solution, because only limited content will be retrieved via a mobile phone.

\section{Broadcast Media and Digital Content}

Radio and TV have wide reach covering around $76 \%$ radio households and $65 \%$ TV households, as compared to $72 \%$ mobile phone households [47]. However, this degree of coverage still leaves several million people outside the realm of daily media reporting. News and drama programming is offered in all 11 languages, though the bulk of TV programming is in four language groups-Nguni, Sesotho, English and Afrikaans. TV sound and picture quality is generally good and local content quotas deliver a reasonable level of local content compared with other African countries, but do not compare favourably with the huge local content industries that have evolved in, for example, India or China. Community radio and television stations, operating as non-profit organisations, offer a neighbourhood perspective on South African life. Of the four community TV stations, Soweto 
Community TV launched in 2006 offers both local and national coverage and is a font of hip, cultural information. The public broadcaster, the SABC, broadcast all 64 games in the FIFA 2010 ${ }^{\mathrm{TM}}$ Soccer World Cup Live on South African radio and TV, ensuring a high percentage participation in this nation-building 6 weeks.

The public broadcaster's role in promoting democracy through offering programming that covers news, current events and the cultural diversity of the country has, however, been diminished by its often weak governance and the parlous state of its finances. These weaknesses have led to attempts at political intervention in the appointment of the Board which should be publicly accountable and independent of the government of the day. It has prompted the rise of the civil society 'Save our SABC coalition', an advocacy group for public accountability of the public service broadcaster. The new Board appointed in 2009 will need a firm yet clever strategy to achieve the delicate balance between promoting increased volumes of local content, digitising existing content and archived materials for availability in new converged formats such as $\mathrm{DTT}^{25}$ and IPTV, ${ }^{26}$ while ensuring effective governance and a trusted public broadcasting model.

\section{South Africa's e-Society}

A consistently productive economy means that South Africa has seen a decade of strong growth. However, after growing at a rate of between 3.1 and 5.8\% per year between 2000 and 2008, the economy contracted by $1.5 \%$ in 2009 due to the effects of the global recession [51: p. 9]. The urban population is estimated at $56 \%$ of the total of 49 million and increasing, with four provinces showing levels of urbanisation greater than $75 \%$ and five provinces showing levels of urbanisation between $10 \%$ and $45 \%$ [46: pp. 21-24]. There is a growing black and female middle class with the requisite disposable incomes to purchase electronic goods and to push forward South Africa's e-development [52].

Simultaneously, a significant proportion of the population is excluded from enjoying the benefits of development. The adult literacy rate for ages 20 years and above hovers around $74 \%$ and poverty levels are high with $22 \%$ of the population or around 10.7 million people living under the poverty line of USD1.25 per day ${ }^{27}$ [39: pp. 48 and 26]. Partly because of its advanced industrial base, South Africa's ICT infrastructure and services are relatively well developed in urban centres, but this belies the state of low levels of e-access for most households and small businesses. The Community Survey 2007 reports that $76 \%$ of households had a working radio, $73 \%$ had mobile phones, $65 \%$ had a working TV, $18.6 \%$ had a landline telephone, $15 \%$ a computer and only $7 \%$ had Internet facilities at home [47].

While computer ownership and Internet access have increased marginally since 2007, the utilisation of ICT in everyday life and the value of electronic banking, online media, electronic government services, digital TV and other household-focused applications is limited to high-income and some medium-income households.

\footnotetext{
${ }^{25}$ DTT is digital terrestrial television

${ }^{26} \mathrm{IPTV}$ is Internet protocol television

${ }^{27}$ ZAR283 per month converted to USD at 7.5 rands to the dollar
} 


\section{Conclusion}

\section{The State of e-Development}

This review of e-development points to two sets of elements required for information society evolution: (a) increasing levels of ICT diffusion and sophistication with respect to information infrastructure, human resources and ICT applications and (b) evolution of the value cycle with respect to ICT production, utilisation and socioeconomic impact. It is argued that the reality of South Africa as a 'connected, information society' remains futuristic. There is only a very small ICT and electronics manufacturing sector, high mobile voice prices, continued low levels of Internet and broadband penetration. ICT penetration is relatively higher in the six large cities, while populations in most small towns and rural areas are excluded from the digital revolution. Policy and regulation has not closed the digital divide and may rather have contributed to its widening.

Why the failure to move towards an inclusive information society? E-development was hemmed in by government policy in the period 1996 to 2008 as a result of government's protection of the powerful interests of the telecoms and mobile operators. Then, a confluence of events, namely the court judgement on VANS selfproviding their own facilities and the award of more than 450 ECNS licences, a slight reduction in broadband prices and the introduction of innovative broadband packages, the gradual opening up of the undersea cable environment, the possible reduction of interconnection rates, potentially sets the scene for more rapid edevelopment post-2010, assuming that other dimensions of e-development do not emerge as binding constraints. Internet usage moved slightly ahead of the curve as evidenced in the 2010 Internet survey figures of 5 million users or roughly $10 \%$ of population. Unfortunately this still limits e-development to the relatively highly industrialised Gauteng province, and to three other metropoles namely the City of Cape Town, eThekwini Metro and Nelson Mandela Metropolitan Municipality.

In the early stage development of the South African information society, government and industry players saw South Africa as a low middle-income country and assumptions were made that the market for value-added services and online media was small in comparison to the voice market. Thus, high telecoms prices aimed at maximising profit from the voice market has been at the heart of the country's limited progress in household connectivity and low levels of Internet-based activity. These high prices were driven by a number of factors, of which two are prominent. In the first instance, from 1997 to 2008 telecommunications policy favoured the incumbent operator, Telkom, by creating a monopolistic environment. It required mobile service providers and VANS to lease their facilities from the fixed-line operator and set the context for a skewed interconnection pricing regime to emerge, with high call-termination rates on the Telkom-owned backbone network. Secondly, restricted ownership of the undersea cable for international voice and data traffic encouraged monopoly pricing on international bandwidth.

Then, in 2008 the Altech High Court judgement enabling new operators and ISPs to build their own facilities networks, broke the government stranglehold on the telecoms sector. It forespelt a confluence of activity including the Neotel deployment 
of fixed mobile infrastructure in metropolitan and urban centres, public debate on interconnection rates leading to the lowering of peak and off-peak mobile call rates, growth in the undersea cable environment introducing cheaper rates for Internet connectivity. This massive programme of infrastructure building alongside a strong push to reduce the price of fixed-mobile and mobile-mobile voice calls and international bandwidth for Internet access is creating a new landscape in which the availability and affordability of infrastructure is encouraging adoption of Internetbased services and online media.

\section{Connected Cities, Disconnected Regions}

It is possible that e-development will push through the barriers of bad policy, regulation and national governance in those parts of the country where the infrastructure and services has become a necessity to the operation of firms and the lifestyles of households, making for perhaps six 'connected cities'-those of Johannesburg, Tshwane, Ekurhuleni, Cape Town, Nelson Mandela Metro and eThekwini. Other smaller cities such as Bloemfontein and Nelspruit, and small towns in locations where populations are highly dispersed, as is the case in the KwaZulu-Natal and Eastern Cape provinces will remain largely disconnected from the highly urbanised hubs where e-development is taking place. Diffusion of advanced ICTs is limited to six cities and sophistication of ICT and Internet-based services is limited to and high- and some middle-income households.

Even within the six cities, there are disconnected segments where households situated far from the urban centres may be living without access to electronic goods and services, except for intermittent SMS messaging on a mobile phone with little capacity for enhanced applications.

\section{Moving Beyond Disconnected Policy}

These disconnected regions mirror the disconnectedness of policy thinking. Policy weaknesses are visible with respect to information society strategy design, with respect to overly bureaucratised approaches to government's responsibilities for policy design and information society leadership, with respect to the limited utilisation of available policy research, and not least with respect to policy flexibility in a highly contested domain for development.

This disconnected policy may be due to the cognitive dissonance experienced by policy-makers who have spent most of their careers in decision-making operating from an industrial paradigm, where strategic thinking and socioeconomic design is exclusively or predominantly influenced by parameters applicable in the industrial age - highly structured, bureaucratised policy-making as compared to flexibility in public policy and strategy design; all powerful decision-makers appointed to make politics-driven rather than evidence-based policy; models of policy-making based on assumptions that changes in the socioeconomic environment occur at a decadal rate of change, whereas change in the technology-society-economy continuum occurs at an increasingly rapid pace in cycles which are yearly or shorter cycles. Indeed, the world is in a transition from an industrial to an information-knowledge-based 
paradigm, hence the two paradigms co-exist, presenting a set of evolutionary policy challenges to which decision-makers must rise.

Future-oriented policy aimed at development of an information society will need to adopt a paradigm that incorporates and integrates the elements of ever greater and more rapid diffusion and sophistication of information infrastructure, side by side with progression in the ICT value cycle from $R \& D$ and new applications to heightened socioeconomic impact, as presented in Fig. 1. The conceptual diagram views policy and regulation; information infrastructure and ICT utilisation and impact as interlocking and contributing factors to the state of e-development. No single factor is totally dependent on the other, nor is any factor necessarily more influential than another in the way in which e-development emerges. Rather, these interlocking factors may have both individual and collective cycles of influence, depending on the particular circumstances and nature of information society evolution in any country.

This 2010 analysis of e-development commenced with a view of South Africa using Hanna's [19] conceptual framework for e-development. It concludes with the following conceptual perspective on e-development and the implications for policy design. The state of e-development in any country can be considered to be affected by (a) the levels of ICT diffusion and sophistication and (b) the value creation cycle arising from the synergies between information infrastructure, ICT utilisation, innovation and impact and policy and regulation. The objective for policy design should be to construct, as far as possible, the basis for synergistic interaction amongst these factors, aimed at increasing diffusion, sophistication and value over time. Indeed, the rapidity with which the ICT applications and online content industries increase in sophistication can be particularly influential in new areas of demand, such as applications for electronic business for micro-businesses and electronic media for low-income households.

Value creation through e-development is pertinent in all economic and social sectors from manufacturing and construction to health and education. Hence, it is necessary to track the evolution of the abovementioned factors in order to understand

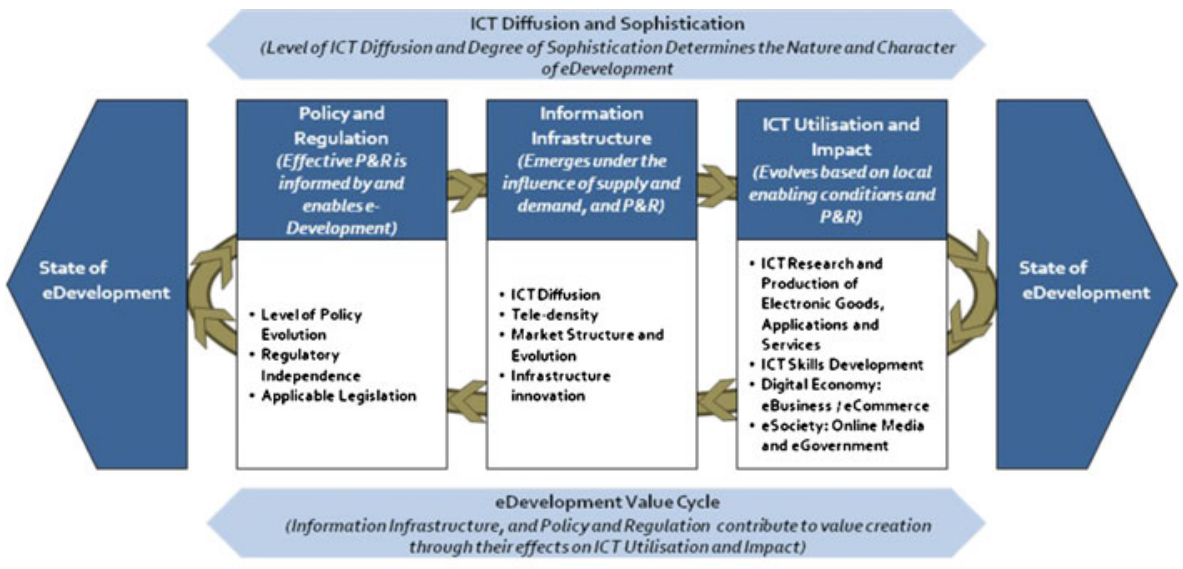

Design: Abrahams. L \& Burke, M. 2010. Wits LINK Centre

Fig. 1 Perspectives on e-Development 
the state of e-development at a given conjuncture in a particular sector, not merely in the broad telecoms or ICT domain. Analysis of the state of e-development can provide valuable evidence and insights for future policy and regulation $(\mathrm{P} \& \mathrm{R})$ that is better able to address the particular complexities of a twenty-first century information society, not simply as a centralised endeavour, but with respect to the best options to promote a wide range of economic growth and social development objectives. Such an approach to information society evolution emphasises the importance of policy-making and leadership across many ministries and all spheres of government.

Acknowledgements This article is based on a LINK public policy research paper co-authored with Arthur Goldstuck.

Open Access This article is distributed under the terms of the Creative Commons Attribution Noncommercial License which permits any noncommercial use, distribution, and reproduction in any medium, provided the original author(s) and source are credited.

\section{References}

1. Abrahams L, Reid L (2008) eGovernance for social and local economic development, Gauteng City region perspective, public policy research paper no 9, LINK Centre. University of the Witwatersrand, Braamfontein

2. Akoojee S, Arends F, Roodt J (2007) ICT skills at the intermediate level in South Africa: insights into private provision and labour market demand, human sciences research council. HSRC Press, Cape Town

3. Benkler Y (2006) The wealth of networks, how social production transforms markets and freedom. Yale University Press, New Haven and London

4. Blake E (1996) Information society and development conference - what was and is happening? unpublished paper, 27 November 1996, Department of Computer Science. University of Cape Town, Rondebosch

5. Business Monitor International (2010) South Africa information technology report (Executive Summary), Quarter 2, 2010, accessed on 29 April from www.businessmonitor.com/it/south africa_information_technology_report

6. Cell $\bar{C}$ South Africa (2009). Positive impact on bottom line, Press release, Cell C, Johannesburg, 22 May 2009, retrieved 15 December 2009 from www.cellc.co.za/content/news/news.asp

7. Claasen L (2010) Money in your phone, financial mail. Business Day Financial Mail, Johannesburg

8. dti (2008) Business process outsourcing and offshoring, 2008 national policy conference, Durban. Department of Trade and Industry (dti), Pretoria

9. DPSA (2001) Electronic government, The digital future. A public service IT policy framework, Department of Public Service and Administration (DPSA), Pretoria, accessed on 2 June 2009 from www.dpsa.gov.za/documents/acts\&regulations/frameworks/IT.pdf

10. DPSA (2008) South Africa's e-government journey: Taking the next step, Presentation at Irene Country Lodge Pretoria, Department of Public Service and Administration (DPSA), Pretoria

11. Dwolatsky B (2010) Interview with the head of the Joburg centre for software engineering. University of the Witwatersrand, Johannesburg

12. Esselaar S, Gillwald A (2007) South African Sector Performance Review 2007, Policy Research Paper No 8, LINK Centre, Graduate School of Public and Development Management, University of the Witwatersrand, Johannesburg, accessed on 30 January 2010 from http://link.wits.ac.za/papers/ TSPR2007.pdf

13. Fraser-Moleketi G (2008) Address to the GovTech conference by the minister for public service and administration, Geraldine Fraser-Moleketi, August 2008, cited in effective e-Government, 4th edn. ITWeb Informatica, Cape Town

14. Gedye, L (2010). ICASA slashes interconnection rates, Mail\&Guardianonline, 15 April 2010, retrieved 30 August 2010, from http:/www.mg.co.za/article/2010-04-15-icasa-slashes-interconnection-rates

15. Goldstuck A (2008) Internet access in South Africa 2008, a comprehensive study of the Internet access market in South Africa. World Wide Worx, Johannesburg

16. Goldstuck A (2009) Online media in South Africa 2009. World Wide Worx, Johannesburg 
17. Goldstuck (2010) Internet access in South Africa 2010, a comprehensive study of the Internet access market in South Africa. World Wide Worx, Johannesburg

18. Goldstuck A, Rabelani D, Gillowey K (2010) Online banking in South Africa 2010. World Wide Worx, Johannesburg

19. Hanna, Nagy K (2009) e-Transformation: Enabling New Development Strategies. Springer, New York

20. Horwitz, Currie W (2007) 'Another instance where privatization trumped liberalization: The politics of telecommunications reform in South Africa -' A ten year retrospective', Telecommunications Policy, Vol. 31 (2007), pp. 445-462.

21. ICASA (2009). Individual electronic communications services, ICASA Notice, Independent Communications Authority of South Africa (ICASA), Sandton, accessed from www.icasa.org.za/ LegislationRegulatory/LicensesandLicensees/ElectronicCommunicationsNetworkService/Individual/ tabid/166/ctl/ItemDetails/mid/949/ItemID/183/Default.aspx

22. James, $\mathrm{T}$ (ed) (2006) Women in the information and communication technology sector in South Africa. icteum consulting and CSIR Meraka Institute, Pretoria.

23. Kew J, Herrington M (2009) ICT \& entrepreneurship. UCT Graduate School of Business, Cape Town

24. Majozi T, Mbuli N, Ferguson K, De Vaal P (2009) Engineering. In: Diab R, Gevers W (eds) The state of science in South Africa, Chapter 10. Academy of Science of South Africa (Assaf), Pretoria, pp 263-275

25. MDDA (2009) Trends of ownership and control of media in South Africa, Report prepared by ZComs. Media Development and Diversity Agency (MDDA), Johannesburg

26. Meraka (n.d.) SANReN - South African Research Network, accessed on 18 June 2009 from www. meraka.org.za/sanren.htm

27. MTN (2008) MTN Group annual report 2008. MTN, Johannesburg

28. NACI (2008) South African science and technology indicators 2008. National Advisory Council on Innovation (NACI), Pretoria

29. Ngcobo Z (2010) Interview with the head of drama. Johannesburg, South African Broadcasting Corporation

30. Nielsen (2007). South Africa's most popular web brands, Nielsen news release, London, 5 December 2007, accessed 3 March 2009 from www.nielson-online.com/pr/pr_071205_ZA.pdf

31. Nielsen (2008) South Africa's most engaging sectors and websites, Nielsen news release, London, 11 July 2008, accessed 3 March 2009 from www.nielson-online.com/pr/pr 080711 ZA.pdf

32. Nielsen (2009) What happened to the South African Internet in 2008? Nielsen news release, London, 8 January 2009, accessed 3 March 2009 from www.nielson-online.com/pr/pr_090108_ZA.pdf

33. NITF (n.d.). After ISAD, Reviewing the ISAD conference: towards the information society in South Africa, National Information Technology Forum (NITF), Johannesburg.

34. Patel I (2010) Interview with senior manager. Department of Science and Technology, Pretoria

35. Patel S (2010) Personal communication with key informant, Consultant with ICT Ventures and Nethealth Solutions, Johannesburg, 23 September

36. Paul Budde Communication (2006) Africa telecoms statistics. Paul Budde Communication Pty Ltd., Australia

37. PRC (1998) Developing a culture of good governance, Report of the Presidential Review Commission on the reform and transformation of the public service in South Africa, Presidential Review Commission (PRC), Pretoria, accessed on 2 June 2009 from www.polity.org.za/polity/govdocs/ reports/presreview/index.html

38. RSA (1996b) Chair's conclusions to the ministerial meetings, Information Society and Development (ISAD) conference, May 1996, Gallagher Estate, Republic of South Africa (RSA) Johannesburg, retrieved 20 June 1997 from http://www.csir.co.za/isad/chaircon.htm

39. RSA (2009) Development indicators 2009, The presidency. Republic of South Africa, Pretoria

40. Schofield A (2008) 2008 ITWeb-JCSE skills survey. ITWeb and Joburg Centre for Software Engineering, Johannesburg

41. Schofield A (2009) 2009 ITWeb-JCSE skills survey: summary of main findings. ITWeb and Joburg Centre for Software Engineering, Johannesburg

42. Seacom (2009a) Seacom goes live, News update, Seacom, retrieved 28 December 2009 from http:// www.seacom.mu/news/news_details.asp?iID $=100$

43. Seacom (2009) Seacom set to drive broadband paradigm shift in SA, News update, 8 June 2009 , accessed on 18 June 2009 from www.seacom.mu/news/news_details.asp?iID=97

44. Smit D, Neilsen B, Roetter M (2008) International peer benchmarking study on the cost to communicate in South Africa. BMI-Techknowledge, Johannesburg

45. Song S (2009) African undersea cables,accessed 15 December 2009 from http://manypossibilities.net/ african-undersea-cables/ 
46. StatsSA (2006) Migration and urbanisation in South Africa, Statistics South Africa, Pretoria, accessed on 15 December 2009 from www.statssa.gov.za/publications/Report-03-04-02/Report-03-04-02.pdf

47. StatsSA (2007a) Community survey 2007-Basic results Gauteng, Statistics South Africa, Pretoria, accessed on 15 December from www.statssa.gov.za/publications/Report-03-01-27/Report-03-01-272007.pdf

48. StatsSA (2007b) Transport, post and telecommunication industry survey, Statistical Release P7000, Statistics South Africa, Pretoria, retrieved 15 December 2009 from http://www.statssa.gov.za/ publications/P7000/P70002006.pdf

49. StatsSA (2008) Post and telecommunication industry 2006, Statistical report 75-01-01(2006), Statistics South Africa, Pretoria, retrieved 15 December 2009 from http://www.statssa.gov.za/ publications/Report-75-01-012006.pdf

50. StatsSA (2009) Annual financial statistics, statistics South Africa, Pretoria, retrieved 15 December 2009 from http://www.statssa.gov.za/publications/P0021/P00212008.pdf

51. Stats SA (2010) Gross domestic product. Statistical Release P0441, 23 February 2010, Statistics South Africa (StatsSA), retrieved 2 December 2009 from http://www.statssa.gov.za/publications/P0441/ P04413rdQuarter2009.pdf

52. Stephens B, Sithole M (2006) Economic success versus political power: A comparison of the black South African middle class and the African-American middle class, Proceedings of the Academy of International Business Southeast USA chapter 2006 annual meeting, Clearwater Beach, Florida, accessed 2 December 2009 from www.aibse.org/Proceedings/Proceedings\%202006/34\%20stevens, \%20sithole.pdf

53. Stones L (2008) Ruling against minister paves way for lower telecoms prices, The Weekender, 1-2 November 2008, cover page

54. Telkom SA (2009). Telkom annual report 2009, Telkom, Pretoria, retrieved 15 December 2009 from https://secure1.telkom.co.za/apps_static/ir/pdf/financial/pdf/Annual_Report_2009.pdf

55. The PNC on ISAD (c2006). Towards an inclusive information society in South Africa. Presidential National Commission on the Information Society and Development: Pretoria.

56. Virgin Mobile South Africa (2009) Virgin Mobile turns profitable, Press release, Virgin Mobile, Johannes burg, 10 November 2009, retrieved 15 December 2009 from www.virginmobile.co.za/press-release.html

57. Vodacom (2009) Vodacom annual report 2009. Vodacom, Midrand

58. Williams M (2009) Interview with government chief information officer. Department of Public Service and Administration (DPSA), Parktown 